Debreceni Jogi Múhely 2015. (XII.) 3-4.

Debreceni Egyetem, Állam- és Jogtudományi Kar, Debrecen

(University of Debrecen, Faculty of Law, Debrecen)

DOI $10.24169 / \mathrm{DJM} / 2015 / 3-4 / 5$

\author{
Nagy Barna Krisztina \\ NKE-NETK Európai Köz- és Magánjogi Tanszék \\ egyetemi tanársegéd
}

\title{
A szindikátusi szerződés
}

Debreceni Jogi Múhely, 2015. évi (XII. évfolyam) 3-4. szám (2015. december)

DOI $10.24169 / \mathrm{DJM} / 2015 / 3-4 / 5$

Jelen tanulmány célja a szindikátusi szerződés fogalmi meghatározásán és jogrendszerbeli elhelyezésén túl, ezen kooperációs kontraktus jellegzetességeinek bemutatása, a kialakult jogirodalmi álláspont és bírói gyakorlat vizsgálata és ennek tükrében saját meglátásom, valamint álláspontom bemutatása. A tanulmány második felében pedig a társasági jog kereteit elhagyva, a kevéssé közismert közjogi elemek és jellegzetességek bemutatására törekszem, nevezetesen a szerződéstípus versenyjogi és közbeszerzési jogi vonásait, mint tisztán más jogági együttmúködést vizsgálom, rávilágítva a vegyes jogági előfordulás lehetőségre.

\section{A szindikátusi szerződés fogalma}

A szindikátusi szerződés a társaságban részt vevő felek céljait, társasággal szemben vállalt kötelezettségeit, elvárásait, a tagok egymáshoz való viszonyát szabályozza.[1] A fogalmi meghatározásból is érzékelhető, hogy a szindikátusi szerződés a társasági szerződésre tekintettel, azzal kapcsolatban jön létre. A társasági szerződés ugyanis - csupán - a szervezeti kérdéseket, valamint a tagok és a társaság viszonyát szabályozza, a társaság múködésére vonatkozó szabályokat tartalmaz. Azonban a tagok egymás közötti, társaságon belüli együttmúködésérôl, a tagok egymással szembeni elvárásairól hallgat (adódóan többek között az iratmintás cégeljárásból). Így szükségesnek mutatkozik egy olyan szerződés, amely a társasági szerződés „hiányosságait” kiküszöböli.

A következőkben rövid bemutatásra szánt társasági jogi szindikátusi szerződés akként írható körül, hogy az egy olyan atipikus együttmúködési kontraktus, amely a társasági jogviszonyhoz járul, a tagok egymáshoz és a társasághoz való viszonyát szabályozza a társasági szerződés által nem érintett körben. Azonban nem szabad elsiklani a szindikátusi szerződés sokoldalúsága felett. Ennek alapján a szindikátusi szerződés egy olyan titkos, csak a jogviszonyban résztvevők által ismert atipikus együttmúködési kontraktus, amely önálló szerződésként (többlet - és részletszabályokat alkotva) szabályozza a felek közötti alapjogviszonyt az általuk megvalósítani kívánt cél elérése érdekében, vagy a felek közötti önálló megállapodás révén a cél elérése érdekében tanúsítandó magatartást, valamint követelményrendszert fekteti le.

\subsection{A szindikátusi szerződés helye a jogrendszerben}

A szindikátusi szerződés jogrendszerben elfoglalt helye kapcsán ki kell hangsúlyozni, hogy a tanulmány első sorban a társasági jogi szindikátusi szerződéssel foglalkozik. Azonban az együttmúködési megállapodások ezen típusa igen sokszínú, ezáltal nem szorítkozhatunk csupán a polgári és társasági jogi jelleg vizsgálatára. Ennél fogva szükségesnek látom a társasági jogi típusú szindikátusi szerződés jogrendszerben, valamint szerződéses rendszerben történő elhelyezését.

A szerződések rendszerében megkülönböztetjük a magánjogi és a közjogi szerződéseket. A magánjogi szerződéseket további két csoportra bonthatjuk: a nevesített és a nevesítetlen szerződésekre. A nevesítetlen szerződések kategóriájába tartoznak az egyedi megállapodások, azaz a de facto innominát 
Debreceni Jogi Múhely 2015. (XII.) 3-4.

Debreceni Egyetem, Állam- és Jogtudományi Kar, Debrecen

(University of Debrecen, Faculty of Law, Debrecen)

DOI 10.24169/DJM/2015/3-4/5

szerződések, valamint a vegyes szerződések, melyek tartalmukban vegyítik egyes szerződéstípusok elemeit, vagy közjogi és magánjogi elemeket egyaránt tartalmaznak. A nevesített szerződések kategóriájába az atipikus és a tipikus szerződések sorolhatóak. Tipikusak azok a szerződések, melyek a Polgári Törvénykönyvben[2] szabályozásra kerültek, atipikusak azok, amelyek a magánjogi kódexünkben (még) nem kaptak helyet, azonban kikristályosodott jellemzőkkel és tartalmi jegyekkel bírnak. Az új Polgári Törvénykönyv hatályba lépésével a korábban bevett gyakorlat megváltozott és több atipikus (bizalmi vagyonkezelés[3], önálló kereskedelmi ügynöki szerződés[4], faktoring szerződés[5], lízing szerződés[6], franchise szerződés[7]), valamint egy nevesítetlen vegyes szerződés (a disztribútori szerződés[8]) is részben vagy egészben - tipikussá vált, és a Polgári Törvénykönyv részét képezi.

A szindikátusi szerződés egy atipikus kontraktus, melyre nézve hazánkban hatályos jogszabály nem tartalmaz rendelkezéseket. Az atipikus jelleget támasztja alá, hogy a jelenleg és azt megelőzően[9]hatályos Polgári Törvénykönyv sem szabályozza, továbbá az elnevezése idegen, amely a legtöbb atipikus szerződés jellemzőjeként jelenik meg, valamint tartalmának kialakítása során a külföldi joggyakorlatnak nagy szerepe volt.

Ennek okán az alkalmazandó jogszabály megtalálása kapcsán segítséget nyújt az az általános érvényú megállapítás, miszerint a szindikátusi szerződés főként személyi és vagyoni viszonyokat szabályoz. Elsőként tehát a polgári jog területén kell keresgélnünk, azonban a magánjogi kódexben található szerződéstípusok egyikébe sem tudjuk egyértelműen besorolni, hiszen a szerződés tárgya és a tartalma rendkívül szerteágazó lehet. A társasági jogi szindikátusi szerződés esetében a szerződés által létrehozott jogviszony kétséget kizáróan a társasághoz, valamint a társasági joghoz kapcsolódik, így ez a helyzet alkalmat teremt a régi Ptk. idején a társasági törvény[10] alkalmazására és figyelembe vételére is, valamint további kapaszkodót jelent a társasági jogi szindikátusi szerződés esetében a régi Gt. 9.\(2) bekezdése, amely szerint e törvény által nem szabályozott személyi és vagyoni viszonyok tekintetében a Ptk. vonatkozó rendelkezéseit kell alkalmazni.A jelenleg hatályos Polgári Törvénykönyv tükrében jogszabályi megkettőződésről értelmetlen beszélnünk, hiszen a Ptk. integrálta a régi Gt-t, így a lexspecialisderogat legi generali elv tükrében a Polgári Törvénykönyv szerződésekre vonatkozó általános rendelkezésein túlmenően a jogi személyekre vonatkozó általános, majd az egyes társasági formákra alkalmazandó speciális szabályok nyernek alkalmazást. Ez a kitétel azonban csak a társasági jogi szindikátusi szerződés esetében alkalmazandó. Ugyanis ha a felek közötti megállapodás a közbeszerzési eljárás során jön létre vagy versenyjogi hatása van, ebben az esetben a vonatkozó ágazati jogszabályokat épp úgy alkalmazni kell, mint a Polgári Törvénykönyv fentebb felvázolt rendelkezéseit, tovább differenciálva az alkalmazandó jog körét.

Az érintett jogterület alapján a szindikátusi szerződés három nagy csoportba osztható: megkülönböztetjük a tisztán társasági jogi szindikátusi szerződést, mely kategóriába sorolható a szavazási megállapodás és a befektetési szindikátusi szerződés; a következő csoportba a tisztán más jogági szindikátusi szerződések tartoznak, melyek lehetnek polgári jogi vagy versenyjogi szerződések, avagy a közbeszerzési jog területére is vonatkozhatnak. Végezetül a harmadik csoportot képezi a vegyes jogági szindikátusi szerződés. A vegyes jogági szindikátusi szerződés jellemzője az, hogy egyidejúleg a szerződés - tartalma alapján - több jogterületet érint.

\subsection{Járulékos vagy önálló szerződés?}

A felek a szindikátusi szerződést a társasági szerződésre tekintettel kötik meg, ezért a szindikátusi szerződésnek addig van értelme és létjogosultsága, amíg a szervezet (gazdasági társaság) létezik, mert megszűnése esetén nem marad olyan keret, ahol a vállalt magatartás gyakorolható.[11] Ez a szindikátusi szerződés járulékos jellegét igazolja. Sárközy Tamás álláspontja szerint a szindikátusi szerződés független önálló szerződés, mert azt a társasági szerződéssel nem egy időben kötik, a szerződés alanyai sem feltétlenül azonosak, valamint a szerződések tartalma is eltérhet egymástól.[12] Véleményem szerint ilyen éles megállapítás nem tehető, ugyanis egyedül a szindikátusi szerződés tartalma adhat választ az önállóság járulékosság kérdésére. Ha a szindikátusi szerződés a szervezet múködése során szabályozza a tagok 
Debreceni Jogi Múhely 2015. (XII.) 3-4.

Debreceni Egyetem, Állam- és Jogtudományi Kar, Debrecen

(University of Debrecen, Faculty of Law, Debrecen)

DOI 10.24169/DJM/2015/3-4/5

egymás közötti viszonyát, kétségtelenül a járulékos jelleg nyer megállapítást, azonban a szindikátusi szerződés a szervezet megszűnését követő élethelyzetekre is tartalmazhat szabályokat. Véleményem szerint ilyen esetekben a járulékos jelleg nem állapítható meg, hiszen nem létezik már az a szervezeti keret, jogviszony, amelyhez „járulhatna” a szerződés, hanem önálló szerződésként, a társasági szerződéstől függetlenül létezik. Bár a társasági szerződés előfeltétele volt a szindikátusi szerződésnek, ezért ezt az önállóságot szerencsésebb a relatív önállóság kategóriájával felruházni. E tekintetben a szindikátusi szerződést szokás Janus - arcú szerződésnek is nevezni.[13]

A bírói gyakorlatban kikristályosodott álláspont szerint a szindikátusi szerződés által szabályozott jogviszony autonóm jogviszony, ugyanis a szerződésben vállalt kötelezettségeket a tartalmuk szerint kell elbírálni,[14] továbbá független, önálló szerződés a gazdasági társaság társasági szerződésétől, a társaság által kötött szerződésektől és a szindikátus tagjai által kötött szerződésektőll.[15] Azonban - a fentiekre tekintettel véleményem szerint - ilyen generális kijelentés nem tehető, a szindikátusi szerződés önállósága - járulékossága kérdésében egyértelmúen állást foglalni nem lehet. Következik ez abból, hogy a hatályos jogunk külön normával, speciális jogszabállyal ezen szerződéstípust nem szabályozza.

A jogi szabályozás hiánya folytán alakszerúségi érvényességi kelléke ezen szerződéstípusnak nincs. Létrejöhet szóban, írásban, ráutaló magatartással egyaránt. „Azonban a gyakorlat következetesen az írásbeliség mellett „tör lándzsát”: nem feltétlenül érvényességi kellékként, inkább biztonsági, bizonyíthatósági szerepe miatt.”[16]A Győri Ítélőtábla Gf. II. 20.341/2010/6. számú ügyében a bíróság a gazdasági társaság legfőbb szerve által hozott határozatokat minősítette szindikátusi szerződésnek: „Az ugyan kétségtelen, hogy a (...) közgyúlési határozat elfogadásával az abban részes részvényesek között szerződés jött létre a gazdasági tevékenységük alperesen keresztüli összehangolására, az alperes által megkötött - nagy volumenű - szállítási szerződések előnyeinek kihasználására és az ebből eredő (több irányú) részvényesi kötelezettségekre. Ez a szerződés azonban nem a formakényszerhez kötött társasági jog által elismert szerződés (azaz: részvénytársaság esetén alapszabály módosítás) volt, hanem a közgyúlési határozatot elfogadó társasági tagok által létrehozott, jogszabályok által nem rendezett atipikus szindikátusi szerződés.”[17]

\section{A szindikátusi szerződés tárgya}

A szerződés tárgya tekintetében kimerító és pontos felsorolás nem adható. A szindikátusi szerződés tárgya és tartalma rendkívül szerteágazó és sokrétű lehet, szindikátusi szerződés ugyanis többféle jogviszonyt szabályozhat. Lehetnek olyan elemei, amelyek kifejezetten a társasági jog körébe tartoznak, de lehetnek polgári jogi, munkajogi, versenyjogi, stb. vonatkozásai is.[18] Mint minden szerződés, a szindikátusi szerződés is bármely, a felek által lényegesnek tartott kérdést szabályozhat annyi megkötéssel, hogy a szerződésben foglaltak ne ütközzenek jogszabályba és lehetőség szerint ne álljanak ellentétben a társasági szerződéssel. A szerződésekre vonatkozó szabályoktól akkor térhetnek el, ha azt a jogszabály nem tiltja (diszpozitivitás).

Az alábbiakban egy példálózó jellegư felsorolásban szeretnék megemlíteni néhány jellegzetes szabályozási tárgykört: a gazdasági társaság révén elérni kívánt célok rögzítése, az ehhez megfelelő tevékenységi körök kiválasztása,[19]mely alapítónak kívánnak elsőbbségi részvényt juttatni,[20] a tervezett jegyzett tôke kapcsán megfelelő kalkuláció készítése (apportlistát nem helyettesítheti),[21] előszerződési tartalom,[22] az estleges jogkövetkezmények jellegéről, ha valamelyik alapítónak felróhatóan hiúsul meg a társaság létesítése.[23]

Ilyen tartalmú szindikátusi szerződés a gazdasági társaság cégjegyzékbe történő bejegyzése előtt is köthető. Azonban, ha a gazdasági társaság cégbejegyzésére nem kerül sor, a szindikátusi szerződés lehetetlenül, azaz a teljesités olyan okból válik lehetetlenné, amelyért egyik fél sem felelős, és így a szindikátusi szerződés megszűnik. A teljesítés lehetetlenné válásáról a tudomást szerző fél haladéktalanul köteles a másik felet értesíteni, ellenkezőleg az értesítés elmulasztásából eredő kárért a mulasztó felelős. A felelősség módja és mértéke kapcsán a szerződésen kívül okozott károkra vonatkozó szabályok alkalmazandóak. A gazdasági társaság bejegyzése előtt megkötött szindikátusi szerződés jogellenes felmondása miatt érvényesített kártérítési követelés elbírálásánál azt is figyelembe kell venni, hogy a társaság tagjai - a cégnyilvántartási 
Debreceni Jogi Múhely 2015. (XII.) 3-4.

Debreceni Egyetem, Állam- és Jogtudományi Kar, Debrecen

(University of Debrecen, Faculty of Law, Debrecen)

DOI 10.24169/DJM/2015/3-4/5

bejegyzés megtagadása esetén - kötelesek a tevékenységüket megszüntetni, ezért a társaság múködéséhez kötődő szindikátusi szerződés teljesítése lehetetlenül.”[24]

A felsorolás további részében olyan szabályozási tárgyak szerepelnek, amelyek a múködő gazdasági társaság esetében bírnak relevanciával: választottbírósági kikötés, jogviták esetére alkalmazandó jog kikötése,[25]jogági kollízió kiküszöbölése,[26]kisebbségi jogok gyakorlása,[27] szavazás,[28]ügyvezetô és ellenőrző szervek összetétele,[29]versenytilalmi megállapodás,[30]társasági nyereség felhasználása,[31] hosszú távú üzletpolitika kialakítása,[32] társaság számára nyújtandó kedvezmény. [33]

A következőkben az egyes szerződési tárgyak közül szeretnék néhányat kiemelni és részletesebben bemutatni.

\subsection{A szavazási megállapodás}

A szavazási megállapodás vizsgálata során a tulajdoni elkülönülés alapelvéből kell kiindulnunk. Az alapelv értelmében az alapítók a vagyoni (és nem vagyoni) hozzájárulásukkal teremtik meg az új jogalany, a gazdasági társaság vagyonát. Ez a rendelkezésre bocsátott vagyontömeg a gazdasági társaság tulajdonába kerül, ez az újonnan alapított jogalany elkülönült vagyona. Ez a vagyon nem képezi a tagok tulajdonát (nem is képezheti, hiszen hatályos magánjogunk a jogalanyon való tulajdonjog fennállását nem engedélyezi), hiszen az elkülönült vagyontömeg perszonifikálódik, azaz jogalannyá válik, függetlenedik előző tulajdonosától. A vagyoni hozzájárulás ellentételezéseként a gazdasági társaság tagja a Ptk-ban és a társasági szerződésben meghatározott tagsági jogait gyakorolhatja. Ilyen tagsági jog például a szavazati jog. A szavazati jog mértékét a társasági szerződés rögzíti. A tag az őt megillető jogát a legfőbb szervi ülésen gyakorolhatja személyesen vagy meghatalmazottja útján. A szavazati jog mértéke a tag által teljesített vagyoni hozzájárulás mértékéhez igazodik, de jogszabály ettől eltérően is rendelkezhet.

A legfőbb szerv a határozatait többnyire egyszerú szótöbbséggel hozza, de a Polgári Törvénykönyv megállapít olyan kivételeket, amikor $3 / 4$-es szótöbbség (kft. esetén a társasági szerződés módosításához) vagy egyhangúság (kkt. és bt. esetén az átalakulás elhatározásához) szükségeltetik a határozatok meghozatalához. Az egyszerú szótöbbséget igénylő határozathozatal esetében problémát jelenthet a szavazategyenlőség, ugyanis erre nézve a Gt. irányadó rendelkezést nem tartalmaz. A Legfelsőbb Bíróság leszögezi, hogy semmis az a társasági szerződési rendelkezés, mely szerint szavazategyenlőség esetén az ügyvezető szavazata dönt: ebben az esetben ugyanis hiányzik a szótöbbség.[34]Mivel a hatályos magánjogunkban a szavazategyenlőség jogintézménye nem ismeretes, nem lehet akként rendelkezni, hogy szavazategyenlőség esetén a tagok valamely tagnak vagy akár az ügyvezetőnek többletszavazati jogot adnak és így döntenek a határozat - tervezet ügyében.[35]A gazdasági társaság tagjai (részvényesei) a közös cél érdekében fokozottabb együttmúködésre kötelesek." [36] Ez az együttmúködés akár szavazási megállapodás formájában is testet ölthet. Bár a szavazási megállapodás elsődleges célja nem a szavazategyenlőség problematikájának kiküszöbölése, hanem a társaság egyes tagjai érdekeinek érvényesülését hivatott biztosítani, mindemellett a tagok nem azonos vagyoni hozzájárulást teljesítenek, így a szavazati arányok sem lesznek egyezőek, ez pedig megnehezíti a 3/4-es szótöbbséget vagy egyhangúságot igénylő döntések meghozatalát. Ezért a probléma feloldására megfelelő eszközként szolgál a szavazási megállapodás. Ez a megállapodás a társasági szerződésben nem kerül szerepeltetésre, így társasági jogi kötőereje nincs, pusztán kötelmi igények érvényesítésére adhat alapot.

A szavazási megállapodás a gazdasági társaság tagjai (alapítók) közötti megállapodás, mely huzamosabb időre szól vagy egyszeri, eseti jelleggel bír. A megállapodás megköthető a társaság alapításakor vagy a társaság múködése során.

A társaság alapítása során a társasági szerződésnek minden esetben tartalmaznia kell a szavazati jog mértékét. Probléma vetődhet fel abban az esetben, ha a szindikátusi szerződés és a társasági szerződés aláirása között újabb tag kíván az alapítók sorába belépni. Ez a szavazás létét a következőképpen érintheti: a tag beleegyezik a szavazásra vonatkozó megállapodásba és taggá válik; vagy számára elfogadhatatlan a megállapodás tartalma és ezáltal az egyezség hiánya folytán nem is alakul meg a gazdasági társaság; vagy a 
Debreceni Jogi Múhely 2015. (XII.) 3-4.

Debreceni Egyetem, Állam- és Jogtudományi Kar, Debrecen

(University of Debrecen, Faculty of Law, Debrecen)

DOI 10.24169/DJM/2015/3-4/5

gazdasági társaság megalakul, de az új, fellépő tag nélkül. A részvénytársaságok esetében annyival árnyaltabb a helyzet, alapításkor nemcsak a szavazati jog mértékét határozzák meg az alapításban részt vevők, hanem felállithatnak egy tényleges szavazási és döntéshozatali mechanizmust, amit a felek nyugodtan rögzíthetnek szindikátusi szerződésben, hiszen a Polgári Törvénykönyv vonatkozó rendelkezései szerint ez nem kötelező tartalmi eleme a társasági szerződésnek. Ilyen esetben a szindikátusi szerződést célszerű benyújtani a Cégbírósághoz, ellenkező esetben a határozat hatályon kívül helyezése esetén a bíróság nem a szavazásra irányuló megállapodást veszi alapul, hanem a vonatkozó jogszabály rendelkezései alapján fog határozni. Ilyen esetben mondhatni semmi értelme sincs a szavazásra vonatkozó szindikátusi szerződésnek, csupán kötelmi igények érvényesítésére kerülhet sor annak megszegése esetén.

A már működő gazdasági társaság esetében is köthető szavazási megállapodás, mely az előzőekben említettek alapján egyszeri alkalomra is szólhat, de huzamosabb együttmúködést is megvalósíthat. Ez utóbbi esetben szavazási konzorciumról beszélhetünk. Ez az együttmúködés kettős célokat szolgálhat: egyrészt egy szűkebb tulajdonosi kör érdekeinek az érvényre juttatását szorgalmazza vagy a gazdasági társaságban a kisebbség szövetkezik egymással annak érdekében, hogy a törvény által részükre nyújtott „védelmet” fokozottabban érvényre juttathassák.

„E véd - és dacszövetség jelleg”[37] óhatatlanul arra enged következtetni, hogy a szavazási konzorcium a magánjogunk által ismert polgári jogi társaságnak feleltethetők meg. Vizsgáljuk meg mélyebben az előbbi kijelentést.

„Polgári jogi társasági szerződéssel a felek (a továbbiakban: tagok) arra vállalnak kötelezettséget, hogy közös céljuk elérése érdekében együttmúködnek, a közös cél megvalósításához szükséges vagyoni hozzájárulást teljesítenek, és tevékenységük kockázatát közösen viselik."[38] A régi Ptk-ban megfogalmazottakkal ellentétben a jelenlegi szabályozásból kimarad az a kitétel, miszerint gazdasági tevékenységet is igénylő közös cél elérésére alapítható a polgári jogi társaság, továbbá a jogalkotó a szerződések körében helyezte el a pjt-re vonatkozó rendelkezéseket, tovább erősítve ezáltal a személyegyesítő, kötelmi jelleget, kibővítve azonban a régi Ptk. polgári jogi társaságra vonatkozó szabályait a gazdasági társaságok irányába mutató szabályozást alkalmazva. Azt azonban nem szabad figyelmen kívül hagyni, hogy a jogalkotó a szerződések körében helyezte el a polgári jogi társaságra vonatkozó szabályokat óhatatlanul is kihangsúlyozva a személyegyesítő jelleget, de ezzel ellentmondásban a jogi személyek szabályozási körében ismeretes szabályozási technikát alkalmaz.

Meglátásom szerint ez nem okoz kardinális változást a pjt. életében, ugyanis a diszpozitív szabályozás folytán a koordinatív pjt. tovább él, bár a Ptk. szerinti fogalmi ismérvek mindegyikével nem fog rendelkezni, de Ptk-n kívüli jogintézményként tovább egzisztál és alkalmazhatóak lesznek rá a Ptk. által kizárólagosan szabályozott vagyonegyesító pjt. rendelkezései.

Mit jelent ez a szavazási megállapodás esetében? Azt, hogy a szavazási megállapodás továbbra is a koordinatív pit-vel mutat szoros összefüggést. A koordinatív pjt. elsődleges célja a tevékenység összehangolása a közös cél elérése érdekében. Ennél fogva a vagyoni hozzájárulás teljesítése nem szükséges, anélkül is létrehozható. A koordinatív pjt. csakúgy, mint a szavazási konzorcium kötelmi jogviszony, hiszen szerződéssel jön létre, közös cél motiválja a szerződő feleket, valamint a jogviszony létesítéséhez vagyoni hozzájárulás nem szükségeltetik.

\subsection{Választottbírósági kikötés}

További lehetséges tárgya a szindikátusi szerződésnek aválasztottbírósági kikötést. Azonban a választottbírósági kikötést tartalmazó szindikátusi szerződés kapcsán kérdésként merülhet fel, hogy a szindikátusi szerződésben szereplő választottbírósági kikötés a társasági szerződéssel kapcsolatos jogvitára alkalmazható - e? Továbbá, ha a társasági szerződés részeként szerepel a választottbírósági kikötés, az kiterjeszthetô - e a szindikátusi szerződésből fakadó jogvitákra? Mielőtt a kérdésekre választ adnék, röviden ismertetném a szindikátusi és társasági szerződés egymáshoz való viszonyát.

A két szerződés viszonya tekintetében nem alakult ki egységes álláspont a jogirodalomban: egyes álláspontok szerint a társasági szerződés és a szindikátusi szerződés nem állhat ellentétben egymással vagy 
Debreceni Jogi Múhely 2015. (XII.) 3-4.

Debreceni Egyetem, Állam- és Jogtudományi Kar, Debrecen

(University of Debrecen, Faculty of Law, Debrecen)

DOI 10.24169/DJM/2015/3-4/5

a Ptk. eltérést nem engedő kógens normáival, ugyanis a jogszabályba ütközés semmisséget von maga után;[39]a másik uralkodó álláspont szerint a szindikátusi szerződés esetében is alkalmazandó az a kitétel, mely szerint a szerződéseket tartalmukban, önállóan kell megítélni és ütközés esetén nem kell az ellentmondást feloldani.[40]

Meglátásom szerint e két markáns álláspont kialakulása ismételten csak a szindikátusi szerződés önálló, illetve járulékos jellegére vezethető vissza. Ha a szindikátusi szerződés járulékos jellegét vesszük alapul, akkor ez az együttmúködési megállapodás önmagában nem létezik, hanem kizárólagosan a társasági szerződéssel összefüggésben jelenik meg, szoros kapcsolatban áll azzal. Ennél fogva a szindikátusi szerződés keretszerződési jelleget ölt, funkciója abban áll, hogy az alapként szolgáló társasági szerződést kiegészítse, pontosítva ezáltal a felek közötti együttműködést. A szerződési tartalom szabad kialakítása a járulékos jellegủ szindikátusi szerződés esetében is érvényesül, azonban a megállapodás megkötése során kiemelt figyelemmel kell lenni - első sorban - a Ptk. jogi személyekre vonatkozó általános és a gazdasági társaságokra vonatkozó speciális (kógens) rendelkezéseire. Az eltérés csak akkor megengedett, ha ezt a jogszabály lehetővé teszi. Ennél fogva a szindikátusi és társasági szerződés nem lehet ellentétes egymással, hiszen szorosan összefonódnak, az egyik kiegészíti a másikat.

A szindikátusi szerződés és a társasági szerződés kapcsolata tekintetében a 1998. 89. BH alapvető megállapításokat tett. A bíróság megállapította, hogy a szindikátusi szerződés vizsgálata során nem választható el az azzal egyidőben kötött, lényegében és alapvetően azzal azonos tartalmi elemeket magában foglaló alapító okirattól. A bíróság kifejtette, hogy a szindikátusi szerződést nevesített szerződésként hatályos jogunk nem szabályozza, azonban a bírói gyakorlat egységesen foglal állást atekintetben, hogy alapvetően polgári jogi szerződésrôl van szó, de ha azt a gazdasági társaság létesítésére tekintettel kötik, olyan szorosan kapcsolódik a társasági joghoz, így a szindikátusi szerződés értelmezése csak a társasági joggal szoros összefüggésben, ennek prioritást adva történhet meg. A határozat szerint a szindikátusi szerződésnek közös megegyezéssel való megszüntetése nem érinti sem a társasági szerződést, sem a gazdasági társaságot, még akkor sem, ha a szindikátusi szerződésnek voltak társasági jogi elemei, vagy magukba foglaltak olyan rendelkezéseket, amelyek a társasági szerződésben is szerepeltek. További megállapítása a bíróságnak, hogy a szindikátusi szerződés a társaságra kötelezettséget nem ró, csupán a részes felek közötti együttmúködésnek minősül.

A szindikátusi szerződés és a társasági szerződés egymáshoz való viszonyának vizsgálatát nehezebbé teszi az, hogy mindkét szerződés eltérő jellemzőkkel rendelkezik: a társasági szerződés mindig nyilvános, ugyanis a cégbejegyzési eljárás során kötelezően be kell nyújtani a cégbíróság részére, ennél fogva a cégnyilvánosság elve kiterjed a társasági szerződésre is. A szindikátusi szerződés esetében ez nem mindig igaz. Főszabály szerint a szindikátusi szerződést nem kell benyújtani a cégeljárás során a cégbíróság részére, ennek eldöntése a felekre van bízva. Némely esetekben ez célszerű, más esetekben pedig hátrányosan érintheti a társaság tagjait. A szavazási megállapodás esetében célszerűnek mutatkozik a szavazásra vonatkozó speciális, többletszabályt tartalmazó szindikátusi szerződés benyújtása az illetékes bíróság számára, hiszen ha a határozat hatályon kívül helyezése során a szindikátusi szerződésre hivatkozunk, ám azt a nyilvánosság nem ismeri, a bíróság nem veszi alapul a felek közötti megállapodást. Előnyös lehet a titokban tartás olyan esetben, ha üzleti titok megőrzésére irányul a megállapodás tartalma, hiszen ezáltal a gazdasági társaság versenypozíciója nem kerül veszélybe. Ez utóbbi folytán a szindikátusi szerződés benyújtásának kötelezővé tétele nem várható el a gazdasági szereplőktől. További különbség a két szerződés között, hogy a társasági szerződés esetében jogválasztásra nincs lehetőség, míg a szindikátusi szerződés esetében - ha abban külföldiek is részt vesznek - megállapodhatnak az alkalmazandó jog kikötésében. „Nincs akadálya annak, hogy egy kéttagú, magyar székhelyű kft. esetében, amelynek egyik tagja magyar, a másik német, a szindikátusi szerződésre nézve a svájci jogot kössék ki mögöttes jogterületként, a szerződés több nyelven készüljön, és a felek mondjuk az angol nyelvú változatot nevezzék hivatalosnak, illetve hogy a társasági jogi vitákban mondjuk a párizsi választottbíróság francia nyelvű eljárását kössék ki."'[41]A szindikátusi szerződés tehát rugalmasabb megállapodás, a társasági szerződéshez képest kényelmesebb megoldást biztosít a felek részére.

Tehát az elóbbiekben feltett kérdések megválaszolásához vissza kell gondolnunk a szindikátusi szerződés járulékos, avagy önálló jellegére. Azaz, ha kizárólag a szindikátusi szerződés tartalmaz választottbírósági kikötést és a szindikátusi szerződés nem függ szorosan a társasági szerződéstől, azaz önálló, a 
Debreceni Jogi Múhely 2015. (XII.) 3-4.

Debreceni Egyetem, Állam- és Jogtudományi Kar, Debrecen

(University of Debrecen, Faculty of Law, Debrecen)

DOI 10.24169/DJM/2015/3-4/5

választottbírósági kikötés nem értelmezhető kiterjesztően, a társasági szerződésből származó jogvitákra nem alkalmazható.[42] Ha a társasági szerződés részeként szerepel a választottbírósági megállapodás és a szindikátusi szerződés szoros kapcsolatban áll a társasági szerződéssel, ebben az esetben a választottbírósági kikötés hatálya a szindikátusi szerződésre is kiterjed.[43] A választottbírósági kikötés kiterjeszthetősége kapcsán a bírói gyakorlat a következőképp foglal állást:

„A társasági tagoknak a társasági szerzódésból fakadó jogvitájára a szindikátusi szerzódésben foglalt választottbirósági kikötést nem lehet kiterjesztöen értelmezni." [44]

Az alapul fekvő ügyben a felek szindikátusi szerződésben állapodtak meg gazdasági társaság alapításáról. A felek úgy rendelkeztek, hogy a szerződésből fakadó vitás kérdéseket választottbírósági úton kell rendezniük, azaz a választottbírósági kikötés egy olyan szindikátusi szerződésben szerepelt, amelyet a gazdasági társaság alapítására tekintettel kötöttek, abban meghatározták az alapítás legfontosabb kérdéseit és rendelkeztek a felek egymás közötti viszonya kérdésében. A későbbiekben a társaság megalapításra került, azonban a társasági szerződésbe a választottbírósági kikötés nem került beemelésre. (Időközben a társaság újjáalakult, alanyváltozás következett be a tagok személyében.) A gazdasági társaság tagkizárásra irányuló határozatot hozott, melynek hatályon kívül helyezését kérte rendes bíróság előtt a tagkizárással érintett. Az alperes az eljárás megszüntetését kérte arra hivatkozással, hogy a szindikátusi szerződésben szereplő választottbírósági kikötés folytán a rendes bíróságnak nincs hatásköre az eljárás lefolytatására. Ennek alapján az elsőfokú bíróság az eljárást megszüntette. A felperes ezt követően fellebbezéssel élt arra hivatkozással, hogy a szindikátusi szerződés már teljesedésbe ment, és ennél fogva a szndikátusi szerződés kikötése a jelen jogvitára nem alkalmazható. Az alperes arra hivatkozással kérte a végzés helybenhagyását, hogy a szindikátusi szerződés ma is létezó, érvényes és hatályos szerződés és az kiegészíti a társasági szerződést. A felperes fellebbezését a bíróság alaposnak találta. Ezt azzal indokolta, hogy a társaság újjászervezése folytán a szindikátusi szerződés alanyai és a társaság alanyai sem azonosak. Továbbá a korábban hatályos Gt.[45] akként rendelkezett, hogy ,a társasági szerződéssel kapcsolatos jogvitákban a Magyar Gazdasági Kamara mellett szervezett Állandó Választott Bíróság jár el, ha a felek ezt a társasági szerződésben (alapszabályban) kikötötték.”[46] Mivel a felek a társasági szerződésben a választottbírósági eljárás lehetőségét nem kötötték ki, így a perre a rendes bíróság hatásköre áll fenn.

Véleményem szerint ez az eseti döntés ma már nem irányadó, ugyanis az 1988. évi VI. törvény a gazdasági társaságokról, valamint a régi Gt. is hatályon kívül helyezésre került.aválasztottbírósági eljárás lehetôségére vonatkozóan egyik Gt. sem tartalmazott ilyen megkötést, csak a választottbíráskodás lehetőséget rögzítették, egyebekben pedig a Vbt. rendelkezéseit tekintették irányadónak. A Vbt. szerint pedig a választottbírósági kikötés a társasági szerződésben is megtehető annak egy pontjaként, illetve külön szerződés is köthető róla, ennél fogva nem csak és kizárólag a társasági szerződésben lehet választottbíráskodásról rendelkezni. Ez az álláspont az új Ptk. fényében is tartható.

„A társasági szerző́désben foglalt választottbirósági kikötést nem lehet kiterjesztóen értelmezni és a szindikátusi szerrếdésböl fakadó jogvitákra is alkalmazni." [47]

Jelen jogesetben a társasági szerződés tartalmazta a választottbírósági kikötést. Az alperes a szindikátusi szerződésben foglalt termékvásárlási és exportkötelességét nem teljesítette és ezzel kárt okozott a gazdasági társaságnak. A felperes a szindikátusi szerződés megszegéséből fakadó kártérítés megfizetése iránt indított pert. A bíróság álláspontja szerint a szindikátusi szerződésben foglalt vételi kötelezettség előszerződés volt a felperes és az alperes között, így tehát az nincs kapcsolatban a társasági szerződéssel, a szindikátusi szerződésben választottbírósági kikötés nem szerepel, a társasági szerződésben szereplő választottbírósági kikötést nem lehet kiterjesztôen értelmezni, ennél fogva az ügy elbírálása a rendes bíróság hatáskörébe tartozik.

Arra nézve, hogy a szindikátusi szerződésben vagy a társasági szerződésben szereplő választottbírósági kikötés a szerződések közötti szoros kapcsolat esetén kiterjeszthetően értelmezhetô - e nem találtam irányadó bírói döntést. Véleményem szerint azonban előfordulhat olyan eset, amikor a kiterjesztő értelmezésre sor kerülhet. Ha egy kkt. tag vagy bt. tag személyes közremúködést vállal a társaság életében, akkor a három lényeges kérdést, miszerint ki végzi, mikor végzi és hogyan végzi a személyes közremúködést, részletesen szabályozni kell. Erre lehetőség nyilik a társasági szerződésben vagy akár a szindikátusi szerződésben is. Utóbbi esetben a társasági szerződés „kiegészitésre” kerül a szindikátusi 
Debreceni Jogi Múhely 2015. (XII.) 3-4.

Debreceni Egyetem, Állam- és Jogtudományi Kar, Debrecen

(University of Debrecen, Faculty of Law, Debrecen)

DOI 10.24169/DJM/2015/3-4/5

szerződésben, és az a társasági szerződéshez járul (járulékos jellegú). Ha a személyes közremúködés nem vagy nem megfelelő teljesítése miatt perre kerül sor és a társasági szerződés választottbírósági kikötést tartalmaz, ez a kikötés kiterjesztően értelmezendő, hiszen a személyes közremúködésre vonatkozó többletszabályok a szindikátusi szerződésben kerültek rendezésre.

\section{A szindikátusi szerződés a versenyjog és a közbeszerzési jog határán}

A társasági jogi szindikátusi szerződéstől kicsit elkanyarodva, a köz- és magánjog határát súroló együttmúködési kontraktust szeretnék bemutatni. Ugyanis a szindikátusi szerződés a tartalmi sokszínűsége okán gyakran a társasági jogi elemeket magában hordozó együttmúködésen túl tisztán más jogági területen jelenik meg, nevezetesen a versenyjogban vagy a közbeszerzési jogban vagy a két jogterület elemeit vegyítve érhetô tetten.

A tisztességtelen piaci magatartás és versenykorlátozás tilalmáról szóló törvény[48] értelmében tilos a vállalkozások közötti minden olyan megállapodás és összehangolt magatartás, amely a gazdasági verseny korlátozását, torzítását vagy megakadályozását célozza, avagy ilyen hatás kifejtésére alkalmas.[49]

A Tpvt. megfogalmazásában a megállapodás tágabb kategóriát jelent a kötelmi jogi szerződéshez képest, gyújtőfogalomként értékeli és minden olyan magatartást, akarategységet a megállapodás körébe vesz, ami alkalmas a fenti tilalmazott hatás vagy hatások valamelyikének kifejtésére. Azonban ez nem zárja ki annak lehetőségét, hogy a felek egy kötelmi jogi megállapodásban a verseny korlátozásáról állapodjanak meg. Erre kifejezetten alkalmas egy szindikátusi szerződés. E tekintetben a megállapodás polgári jogilag egy szúkebb kategória, mert akár szerződés részeként is megjelenhet a tilalmazott magatartásban való megállapodás.

A fentiek támasztja alá a Versenyhatóság azon gyakorlata, miszerint versenyjogi szempontból nem akkor jön létre egy, a Tpvt. 11.§-ába ütköző megállapodás, ha azt a szerződő felek polgári jogi vagy társasági jogi alapon érvényesen aláírják, hanem akkor, amikor a megállapodásban rögzítettekre vonatkozóan a felek közötti akarategyezség megállapítható. A tiltott megállapodáshoz - jelent esetben a szindikátusi szerződéshez - nem szükséges feltétel az, hogy az polgári jogi vagy társasági jogi értelemben érvényes legyen, illetve az sem, hogy az bármilyen írásbeli formát öltsön. Szükséges és egyben elegendő feltétel, ha az érintett felek akarategysége megállapítható vagy a felek megállapodásra utaló magatartást tanúsítanak.[50]

A jogsértés megállapításához nem szükséges továbbá, hogy a felek előzetesen egy átfogó tervben állapodjanak meg. A törvényi tilalom ugyanis kiterjed olyan, az egyezkedési folyamat során létrejövő be nem fejezett egyetértésekre, részleges és feltételes megállapodásokra, amelyek összességükben vezetnek aztán egy végleges megállapodásra. A jogsértésnek nem feltétele a megegyezésnek megfelelő magatartást kikényszerítő szankciórendszer kidolgozása sem.[51]

A joggyakorlat világosan megkülönbözteti egymástól a versenykorlátozó megállapodás megkötését és annak végrehajtását. A versenykorlátozó megállapodás végrehajtásának hiánya nem eredményezi a megállapodás megkötése miatti felelősség kizárását. A kartellnek, azon belül is az átfogó tervnek megfelelő piaci stratégiával ellentétes versenyző magatartás tanúsítása a felelősség alól nem mentesít, azonban az eljáró versenytanács ezen körülményt az érintett eljárás alá vont vállalkozások javára veszi figyelembe a bírságkiszabás során.[52]

A fentiek alátámasztására álljon itt egy jogeset: a perbeli esetben a másodfokú bíróság által pontosított tényállás szerint a felperesek sütőipari tevékenységet folytattak; a szolgáltatásukkal érintett településen és annak 50-60 km-es körzetében más pékségek is (több mint 60) árusították termékeiket. A II.r. felperes ügyvezető igazgatója 2002. február 27-i keltezésű levelében a település kenyér és pékáru ellátása témakörben „közös együttgondolkodásra" pékségeket hívott meg 2002. március 5-én a polgármesteri hivatal tanácskozó termébe. A megbeszélést többen ipartestületi jellegú ülésnek tartották. A találkozónaz árak, az áremelés szükségessége, a növekvő költségek is szóba kerültek, egyebekben sürgették az összefogást a multinacionális cégek 2001-2002 fordulóján tapasztalt árletörő, a növekvő költségeket érvényesíteni kívánó pékségek által tett árajánlatokat sorozatosan elutasító árpolitikájával szemben. A 
Debreceni Jogi Múhely 2015. (XII.) 3-4.

Debreceni Egyetem, Állam- és Jogtudományi Kar, Debrecen

(University of Debrecen, Faculty of Law, Debrecen)

DOI 10.24169/DJM/2015/3-4/5

levezetô elnök e körben hivatkozott szlovéniai példákra és arra, hogy Egerben 125 forintos átadási árban egyeztek meg a pékek a fehér kenyér vonatkozásában, továbbá az Ipartestület és az APEH közös ellenőrzésére, amelynek során megállapításra került az a minimális költség, amelyet az árakban mindenképpen érvényesíteni kell. A levezető elnök konkrétan a $120 \mathrm{Ft} / \mathrm{kg}$ átadási árat javasolta a fehér kenyérre nézve és bevezetési időpontként 2002. március 18. napját. Az ülésen résztvevők egyetértettek abban, hogy a költségek növekedése jelenjen meg az árakban is.Mindezek alapján a másodfokú bíróság bizonyítottnak találta, hogy a 2002. március 5. napján megtartott megbeszélés során a jelenlévők áregyeztetést folytattak, egységes áremelést szorgalmaztak, minimálár bevezetéséról tárgyaltak, bár írásbeli és szóbeli megállapodás e körben nem született, de az árkialakítás tekintetében egy akarategység jött létre közöttük.[53]

A közbeszerzési eljárás egy folyamat, egy speciális versenyeztetési eljárás, amelyet a Közbeszerzési törvényben[54] taxatíve meghatározott ajánlatkérő indít, és amelynek során szigorú alaki és tartalmi szabályok betartása és betartatása mellett lehet versenyeztetni az ajánlattevőket. Az eljárás célja minden esetben az optimális ajánlat megtalálása. Mivel a piaci szereplők versenyéről van szó, elkerülhetetlen a közbeszerzési jog versenyjoggal való kapcsolódásának vizsgálata.

A perbeli esetben[55] a közbeszerzési eljárás egy ingatlan teljes körú felújítására, átalakítására és a kapcsolódó kivitelezői, szakipari munkálatok elvégzésére közbeszerzési eljárás került meghirdetésre. I. és II. rendủ felperesek az eljárás során kapcsolatba léptek egymással megállapodás megkötése céljából azzal a tartalommal, hogy bármelyikük is nyer a közbeszerzési eljárás során, a vesztest kárpótlásul bevonja a beruházásba. Az elképzelések között az alvállalkozói szerződés megkötése, a másik javára a versenytől való visszalépés, illetőleg az is szerepelt, hogy közös gazdasági társaságban tevékenykednek tovább e tender megvalósítása érdekében.

A későbbiekben III. rendű felperes megállapodásba történő bevonásáról döntöttek a felek. A megállapodás szerint III. r. felperesnek közös gazdasági társaságot kellett létrehoznia, illetőleg ennek keretén belül alvállalkozói szerződést kötnie a vesztessel.Ezt követően elkészült a szerződéstervezet, de valamennyiük aláírása elmaradt.

Az eljárás során II. rendű felperes tette meg a nyertes ajánlatot, így vele kötötte meg ajánlatkérő a közbeszerzési eljárást lezáró vállalkozási szerződést a fenti munkák kivitelezésére.A megállapodásnak megfelelően II. és III. rendű felperesek a terv szerint megalapították a szóban forgó Kkt-t. Az alvállalkozói szerződéseket a Kkt. kötötte, amelyről a nyertes II. rendű felperes az ajánlatkérôt nem tájékoztatta, valamint az ajánlatkérô a gazdasági társaság megalapításáról sem tudott.

A fenti jogeset egy a közbeszerzési eljárás során tipikusnak mondható magatartást és megállapodás típust mutat be. A felek közötti megállapodás tovább árnyalható azzal, hogy a három ajánlattevő közül kettő érvénytelen ajánlatot tesz annak érdekében, hogy a harmadik nyerjen és ellentételezésként a nyertes fél a többi, megállapodásban szereplő ajánlattevőt alvállalkozóként alkalmazza.

A fent hivatkozott jogeset kapcsán a Gazdasági Versenyhivatal hivatalból versenyfelügyeleti eljárást indított, mely helyszíni vizsgálati eljárása során fellelte, majd lefoglalta a felek megállapodását tartalmazó szindikátusi szerződést, valamint egy Együttmúködési megállapodást, melyek kapcsán megállapította, hogy I., II. és III. rendû felperesek a közbeszerzési eljárás során a gazdasági versenyt korlátozó magatartás tilalmába ütköző magatartást tanúsított és felpereseket versenyfelügyeleti bírság megfizetésére kötelezte.Az alperes (Gazdasági Versenyhivatal) a Tpvt. 11.§-ának (1) bekezdésére utalva rögzítette, hogy az eljárásban vizsgált magatartás kartell tilalomba ütköző, függetlenül attól, hogy az szúkebben vett megállapodás (akarat, egyezség), vagy összehangolt magatartás formájában valósult meg. Rámutatott arra, hogy az I.r. és II.r. felperes elismerten a részletes ajánlat benyújtását megelőzően felvette egymással a kapcsolatot, amely magatartásuk a pályázat végső kimenetelét befolyásolta. A fellelt Szindikátusi szerződés I. változata alapján - melyet az I. és II. rendû felperes aláirt - úgy értékelte, hogy közöttük akarategyezség jött létre, és az alá nem îrt megállapodás tekintetében is a felek megállapodásra jutottak, amely elegendő a jogsértés megállapításához. 
Debreceni Jogi Múhely 2015. (XII.) 3-4.

Debreceni Egyetem, Állam- és Jogtudományi Kar, Debrecen

(University of Debrecen, Faculty of Law, Debrecen)

DOI 10.24169/DJM/2015/3-4/5

A versenyjogi aspektus igazán az ún. körbenyeréses módszer[56] kapcsán érhetô tetten. Ennek az együttmúködésnek az a lényege, hogy a közbeszerzési eljárásban résztvevők folyamatosan kapcsolatban maradnak egymással, újra és újra megkötik a szindikátusi szerződést és a szerződésekben a nyertes ajánlattevői és az alvállalkozói pozíciót „forgatják” egymás között. Ez a megállapodás piacfelosztó kartellként minősül abban az esetben, ha földrajzi területekre vetítve osztják fel egymás között az egyes pozíciókat. Erre példa a Gazdasági Versenyhivatal Versenytanácsának Vj-27/2003/16. számú határozata, amikor a Nemzeti Autópálya Rt. az autópályaszakaszok építésére kiírt közbeszerzési eljárás során állapodtak meg kifejezetten az autópálya - építési munkálatok felosztásáról.

A további példaként szolgáló jogesetben a Versenytanács megállapította, hogy a szóban forgó gazdasági társaságok a gazdasági verseny korlátozására alkalmas, egységes és folyamatos magatartást tanúsítottak, amikor egy meghatározott időszakban több út- és hídépítési, illetve felújitási közbeszerzési pályázat kapcsán felosztották egymás között a piacot és rögzítették az eladási áraikat.[57] A Gazdasági Versenyhivatal versenyfelügyeleti eljárást indított, mert a szóban forgó közbeszerzési eljárások során a felek több pályázat esetében megállapodtak a várható nyertes személyéről és a többi vállalkozás alvállalkozóként történő foglalkoztatásáról. Az eljárás alá vontak közigazgatási határozat bírósági felülvizsgálata tárgyában pert indítottak, ahol a perre illetékes bíróság is helybenhagyta a versenytanácsi határozatot. [58]

\section{4. Összegzés}

A társasági jogi szindikátusi szerződés további létét illetően a Polgári Törvénykönyv jogi személyek létesítésére vonatkozó rendelkezéseit kell górcső alá vennünk. A hivatkozott rendelkezés szerint bárki létesítő okiratban szabadon létesíthet jogi személyt, annak szervezetét és múködési szabályait maguk határozhatják meg. Tehát a régi Gt. és jelenleg hatályos Ctv.[59]kógenciájával szemben a Ptk. egyértelmúen a diszpozitivitás mellett tör lándzsát. A vizsgált szerződéstípus kapcsán kérdésként merülhet fel az olvasóban, miként érinti a hivatkozott rendelkezés a tanulmányban vizsgált együttmúködési kontraktust.

A válasz nagyon egyszerú: a diszpozitivitás ebben az esetben egyértelmúen a szindikátusi szerződés háttérbe szorítását, kis idővel annak a gyakorlatból való kiszorítását célozza. Hiszen a létesítő okiratban a felek szabadon döntenek a jogi személy létét érintő kérdésekről, így a kógencia hiánya nem indokolja a társasági szerződést kiegészítô kooperációt. Azonban ennek ellensúlyozására és a szabályozás naivitására három érvet szeretnék kiemelni.[60] Az első és legfontosabb érv a szindikátusi szerződés titkossága. A felek személyes kapcsolatot, elvárásokat szabályoznak a szindikátusi szerződésben, ezért semmiképp sem szeretnék, ha az transzparens módon a kívülállók számára is ismert lenne. A diszpozitív társasági szerződés esetében ez elképzelhetetlen, amint a cégiratok közé kerül, a cégnyilvánosság elve folytán mindenki számára megismerhető lesz és ez a gondolat át is vezet a következő érvre, nevezetesen arra, hogy a Ctv, kógens, rendelkezéseit megkerülve társaságot alapítani ma Magyarországon nem lehet. Ennél fogva a felek semmilyen formában nem tudják elérni, hogy a személyes viszonyrendszerüket szabályozó társasági szerződés, legalább a viszonyrendszer tekintetében rejtve maradjon. Egyetlen választásuk marad, a szindikátusi szerződés megkötése. Harmadsorban pedig nem szabad megfeledkeznünk az egyszerúsített cégeljárás lehetőségéről, mint pénzt és időt kímélő nemperes eljárásról. „Diszpozitív társasági szerződés” esetén ennek lehetőségétól a felek elesnek.

Összegzésként elmondható, hogy a szindikátusi szerződés léte továbbra is indokolt, azon jogalkotói szándék, mely ezen szerződéstípus háttérbe szorítására irányul - meglátásom szerint - nem fog sikerre vezetni. A szindikátusi szerződés nem veszítette és soha nem is veszíti el aktualitását, valamint a titkosságában rejlő előnyöket.

\section{Summary - The syndicate agreement}

Before the new codex of civil law the law of business associations was cogent, that is why the syndicate agreement became a popular contract again. Yes, I would like to emphasize again, because in the past decade, after the commercial law became valid, this type of agreement and cooperation, what was 
Debreceni Jogi Mühely 2015. (XII.) 3-4.

Debreceni Egyetem, Állam- és Jogtudományi Kar, Debrecen

(University of Debrecen, Faculty of Law, Debrecen)

DOI 10.24169/DJM/2015/3-4/5

regulated by the syndicate agreement was well known in the Hungarian civil law. Namely this commercial law had a provision, which said, that every occasional associations i.e. civil association or consortiums, are actually civil associations not business associations. The bottom line is, they are contractual collaborations, with one purpose, to make profit. If someone comes to make this kind of cooperation/collaboration, it has to be regulated by a syndicate agreement.

After the WWII, the syndicate agreement was not popular. By the time when the first law of business association entered into force, this type of cooperation reached high popularity, because of the cogent rules, in respect of the private limited company. This is the reason why the syndicateswith vote became so popular,and they will be after a dispositive civil codex.

First I would like to present syndicate agreement of company law, second I would like to give a brief overview about the syndicate agreement of public law.

[1]Balásházy Mária: A szindikátusi szerződés a társasági és a polgári jog határán, Gazdaság és Jog, 1993/5.; 16.

[2] 2013. évi V. törvény a Polgári Törvénykönyvről, továbbiakban: Ptk.

[3] Ptk. 6:310-6:330. SS

[4] Ptk. 6:288 - 6:301. JS

[5] Ptk. 6:405 - 6:408. SS

[6] Ptk. 6:409-6:415. SS

[7] Ptk. 6:376-6:381. SS

[8] Ptk. 6:372-6:375.0S

[9] 1956. évi IV. tv. a Polgári Törvénykönyvről, továbbiakban: régi Ptk.

[10] 2006. évi IV. tv. a gazdasági társaságokról, továbbiakban: Gt.

[11] Jenovai Petra - Papp Tekla - Strihó Krisztina - Szeghő Ágnes: Atipikus szerződések, Lectum Kiadó, Szeged, 2011, 33.p.)

[12] Sárközy Tamás: A szindikátusi szerződésről, Eörsi Gyula Emlékkönyv, HVG - Orac, Budapest, 2002, 177.

[13] Lukács Mónika - Sándor István - Szűcs Brigitta: Új típusú szerződések és azok gyakorlata a gazdasági életben, HVG - ORAC, Budapest, 2013, 47-48.

[14] BDT 2007.1671.

[15] GYÍT Gf. II.20.118/2009/4.

[16]Jenovai - Papp - Strihó - Szeghő i. m. 13.

[17] GYÍT Gf. II. 20.341/2010/6.

[18] BH 1998.89.

[19]Kolben György: A szindikátusi szerződés, KJK, Budapest, 1996, 32.

[20]Kolben Gy. i. m. 38.

[21] KGD 1997.173.

[22]Haitsch Gyula: Szerződés létrehozásának mellőzése előszerződés alapján annak következtében, hogy a szerződés tartalma nem határozható meg, Gazdaság és Jog, 2003/3., 25 - 26.

[23] Juhász József „Szerződések ütközése Kft-ken belül avagy felesleges duplicitás?” (Magyar Jog , 1991/12., 731.p.) 
Debreceni Jogi Múhely 2015. (XII.) 3-4.

Debreceni Egyetem, Állam- és Jogtudományi Kar, Debrecen

(University of Debrecen, Faculty of Law, Debrecen)

DOI 10.24169/DJM/2015/3-4/5

[24] EBH 2006. 1428

[25] Lukács - Sándor - Szűcs i. m. 47

[26]Balásházy M. i. m. 16.

[27]Balásházy M. i. m. 17.

[28]Kolben Gy. i. m. 107.

[29]Jasztrabszki T. i. m. 8.

[30] Lukács - Sándor - Szúcs i. m. 31.

[31] Juhász József: Cégkörökben gyakoribb atipikus szerződések I., Céghírnök, 2009/4., 11 - 12.

[32]Balásházy M. i. m. 17.

[33] Pécsi Ítélőtábla Gf IV. 30 203/2008/3.

[34] BH 2000.553.

[35] EBH 2000.229. II.

[36] Auer Ádám - Bakos Kitti - Buzási Barnabás - Farkas Csaba - Nótári Tamás - Papp Tekla „Társasági jog, Lectum Kiadó, Szeged, 2011, 155.

[37] K. P., Cégvezetés 1997/3., 28.

[38] Ptk. 6:498. \$

[39]Jasztrabszki T. i. m. 7.

[40] Sárközy T. i. m. 188.

[41] Sárközy i. m. 187.

[42] Lukács - Sándor - Szűcs i. m. 68. alapján

[43] Lukács - Sándor - Szűcs i. m. 68.alapján

[44] BH 1992. 772

[45] 1988. évi VI. törvény

[46] 1988. évi VI. tv. 18. S.

[47] BH 1994. 424.

[48] 1996. évi LVII. tv., továbbiakban: Tpvt.

[49] Tpvt. 11. (1) bek.

[50] VJ 028/2013., VJ 145/2001., VJ 27/2013/16.

[51] VJ 040/2013., Vj 145/2001.

[52] VJ 74/2011

[53] FÍT 2.Kf.27.713/2006/6.

[54] 2011. évi CVIII. tv., továbbiakban: Kbt.

[55] FÍT 2.Kf.27.232/2007/14. (versenyügyben hozott közigazgatási határozat bírósági felülvizsgálata: VJ 28/2003/47)

[56] Juhász Ágnes: Közbeszerzés a versenyjog határán, Miskolci Jogi Szemle, 2010, 143.

[57] VJ 130/2006/239

[58]Kfv.II.37.076/2012/28. 
Debreceni Jogi Múhely 2015. (XII.) 3-4.

Debreceni Egyetem, Állam- és Jogtudományi Kar, Debrecen

(University of Debrecen, Faculty of Law, Debrecen)

DOI 10.24169/DJM/2015/3-4/5

[59] 2006. évi V. tv. a cégnyilvánosságról, a bírósági cégeljárásról és a végelszámolásról

[60]Lásd, egyetértésben: Papp Tekla: Atipikus szerződések, Opten Kft, Budapest, 2015. (o. n.) 